\title{
STUMP ON FORGIVENESS
}

\author{
Richard Swinburne
}

\begin{abstract}
I claim that all the criticisms made by Eleonore Stump in her Atonement of my account of the nature and justification of human and divine forgiveness are entirely mistaken. She claims that God's forgiveness of our sins is always immediate and unconditional. I argue that on Christ's understanding of forgiveness as deeming the sinner not to have wronged one, God's forgiveness of us is always conditional on our repenting and being willing to forgive others. Her account of forgiveness merely as the expression of love for the sinner leaves her without a separate word for the all-important act of "wiping the slate clean." Unlike Stump, I endorse the account in The Letter to the Hebrews of Christ's passion and death as a sacrifice for human sin.
\end{abstract}

Eleonore Stump's Atonement is a brilliant exposition of a totally new theological interpretation of how the Passion and death of Jesus Christ on the cross made it possible for humans to be at-one with God. In doing so, she rejects all other interpretations as seriously deficient. She regards her own interpretation as a development of the imperfect interpretation provided by Aquinas; and has strong criticisms of the only other kind of interpretation prevalent in the last thousand years, which is that of Anselm. She recognizes that my own theory, contained in my book Responsibility and Atonement, is a version of Anselm's theory, and claims that it is subject to most of the criticisms which apply to Anselm's own version. I argue that none of her criticisms of Anselm have any force against my version of Anselm's theory. I claim in particular that she understands "forgiveness" in a totally different way from Christ as reported in the Gospels, and that she fails to bring out the moral importance of "forgiveness" in what I believe to be Christ's understanding of it.

\section{$I$}

My version of Anselm's account of human wrongdoing and its consequences is that A wrongs $B$ if and only if $A$ fails to render to $B$ what is due to him/her, and thereby A acquires guilt; A's guilt is removed if A makes atonement to $\mathrm{B}$ and in consequence $\mathrm{B}$ forgives $\mathrm{A}$. A makes atonement to $B$ if $A$ repents, apologises to $B$, makes reparation (that is, compensation which Anselm calls "satisfaction") to B and gives to B a little extra as well 
which I call "penance." In response to such atonement, it is good for B to "forgive" A. According to Anselm, ${ }^{1}$ A must make full reparation and penance to B for B to be justified in forgiving A. Stump is however mistaken in attributing to me this simple view that satisfaction is "a prerequisite for forgiveness." ${ }^{2}$ My view was more nuanced: "Not all [repentance, apology, reparation, and penance] are needed in every case. For some wrong reparation is inappropriate... But sincere apology [that is, apology resulting from repentance] is always needed"3; and "in the case of a serious hurt... the wrongdoer must offer some attempt at reparation in so far as it lies within his power. But the victim may if he chooses let the wrongdoer off more." ${ }^{4}$ According to both Anselm and me, someone else can provide the reparation for $A$ to offer to $B$. In my view $B$ has no obligation to forgive A, even if he has made full atonement to A, although in this case A's guilt would eventually disappear.

In applying his account to sin in the sense of wronging God, Anselm claims that we must indeed repent and apologise to God for our sins; but since we are unable to make reparation (and penance), God must provide them himself (by becoming incarnate and suffering and dying on the cross) if it is to be possible for him to forgive us. Aquinas modified this account by claiming that God could have forgiven us without demanding "satisfaction," if he had so chosen; and it would not have been wrong of him so to choose; ${ }^{5}$ Aquinas did however hold that it was better that God should forgive us "by Christ's passion than by God's will alone." ${ }^{\prime 6}$ endorsed this Thomist view, on the grounds that by providing us with a reparation in the form of Christ's passion which we can offer to God, together with our repentance and apology, as our reparation (and penance) for our sins, God takes seriously and forces us to take seriously the depth and extent of human wrongdoing. We make our repentant apology paradigmatically before receiving the sacraments of baptism and the eucharist, which constitute the application to us of Christ's Passion and death.

Stump criticises any Anselmian view that forgiveness cannot or should not be given unless the wrongdoer does something (whether just repenting and apologizing, or perhaps more than that) which makes forgiveness appropriate. In Stump's view forgiveness is "an expression of love; and love is necessary and sufficient for forgiveness." ${ }^{\prime 7}$ She seems to accept what she regards as Aquinas's view that "love is obligatory," 8 and clearly accepts the view which she finds in Aquinas that there is an unconditional obligation

\footnotetext{
${ }^{1}$ Anselm, Cur Deus Homo, 1.11.

${ }^{2}$ Stump, Atonement, 446n118.

${ }^{3}$ Swinburne, Responsibility and Atonement, 84.

${ }^{4}$ Swinburne, Responsibility and Atonement, 86.

${ }^{5}$ Aquinas, Summa Theologiae, IIIa 46, 2 ad 3.

${ }^{6}$ Aquinas, Summa Theologiae, IIIa 46, 3.

${ }^{7}$ Stump, Atonement, 438n47.

${ }^{8}$ Stump, Atonement, 82.
} 
on everyone to forgive those who wrong them. ${ }^{9}$ So, Stump holds - contrary to Anselm - that as God always loves all humans, he always automatically forgives them, the moment they sin.

As Stump acknowledges (especially in a subsequent paper ${ }^{10}$ ), "forgive" can be used in more than one sense. But Stump has a preferred sense. Although (strangely, in view of her major concern with this concept in a very large book) Stump writes that "it is not part of my purposes here to define forgiveness,"11 by which she must mean "to define her sense of forgiveness," what she writes (cited above) is naturally interpreted as claiming that in her sense to "forgive" someone who has wronged you is simply to express love for that wrongdoer. I am happy to agree with her that it is always good to "forgive" a wrongdoer in her sense of "forgive" (though I would deny that it is always obligatory). But, I suggest, that is not the sense in which the Gospel writers used the word $\alpha \varphi$ in $\mu$ เ to report Christ's teaching about what is normally described in English as "forgiveness"; and if we wish to understand Christ's teaching about forgiveness, we should interpret it as concerned with "forgiveness" in his sense. For Christ, wrongdoing is depriving someone of something which belongs to them, be it money, possessions, service, respect, or whatever, and so in a wide sense incurring an (unauthorized) debt; and forgiving is analogous to remitting that debt, and so deeming the wrongdoer no longer to owe anything and so to be in the same position as someone who had never incurred a debt. Matthew (6:9-13) and Luke (11:2-4) record Jesus teaching his disciples to say "the Lord's prayer," in which we are told to pray "for-

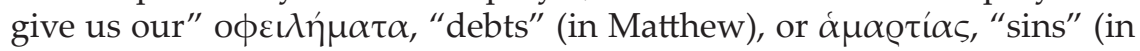
Luke). ${ }^{12}$ That is, Christ's own word (probably in Aramaic) for what we should forgive was regarded as translatable either as "debts" or "sins." In Christ's parable of the unmerciful servant (Matthew 18:23-35) the servant who had a large debt remitted by his Lord (after he had asked the Lord for mercy) tried to extort a small debt owed to him by a fellow servant. When the Lord heard about this, he handed over the unmerciful servant to be tortured "until he should pay the entire debt. So my heavenly Father will also do to every one of you if you do not forgive ( $\alpha \phi i ́ \eta \mu \mathrm{L})$ your brother or sister from your heart." So again, sinning is analogous to incurring an (unauthorised) debt; and forgiving a sinner is analogous to deeming them to be in the same position as someone who had never incurred a debt. For this reason I defined B forgiving A as B undertaking that in the future he/ she will not treat $\mathrm{A}$ as the originator of an act by which $\mathrm{A}$ wronged $\mathrm{B}_{r}^{13}$ forgiving "wipes the slate clean."

\footnotetext{
${ }^{9}$ Stump, Atonement, 82.

${ }^{10}$ Stump, "The Doctrine of the Atonement."

${ }^{11}$ Stump, Atonement, 438n47.

${ }^{12}$ Biblical quotations are from the New Revised Standard Version.

${ }^{13}$ Swinburne, Responsibility and Atonement, 85.
} 
Other statements of Christ, as quoted in the Gospels, also state or imply that God will forgive us if and only if certain conditions are satisfied. There seem to be two such conditions. The first is that we make a sincere apology, that is show our repentance by apology, or at least show that we want to do so. Luke 17:3-4 records Christ as teaching that "If another disciple sins, you must rebuke the offender, and if there is repentance, you must forgive. And if the same person sins against you seven times a day, and turns back to you seven times and says, 'I repent', you must forgive." This seems to imply that if the wrongdoer does not "turn back" and repent, he need not be forgiven. More explicitly Matthew 18:15-20 represents Christ as teaching that if a church member is judged by the church, after taking evidence from witnesses, to have sinned, and still refuses to listen to the church's rebuke, "let such a one be to you as a Gentile and a tax-collector." This clearly implies that we should not "forgive" those who refuse to repent, in the sense of "forgive" which entails treating the wrongdoer as though they had not done wrong. The parable of the two debtors suggests that Christ expects God to deal with us in the way in which Christ teaches us that he wants us to deal with others; and so we cannot expect God to forgive us unless we repent and apologise (or at least show that we want to do so). The second condition for us receiving divine forgiveness is that we forgive (presumably in response to their repentant apology) those who have wronged us. One only asks for what one does not already have; in the Lord's prayer we ask for forgiveness, and provide as reason why God should forgive us that we are forgiving others. In the parable of the debtors, the Lord withdrew his forgiveness when the unmerciful servant did not forgive his fellow servant. And in Matthew 6:15, Christ comments that if you do not forgive humans their faults ( $\pi \alpha \varrho \alpha \pi \tau \omega \mu \alpha \tau \alpha)$, "neither will your heavenly Father forgive your trespasses." Christ's words quoted in Mark 11:25 also emphasise this condition: "Whenever you stand praying, forgive, if you have anything against anyone; so that your Father in heaven may also forgive you your trespasses ( $\pi \alpha \varrho \alpha \pi \tau \omega \mu \alpha \tau \alpha)$." Our forgiveness would clearly still need to be conveyed in words or by our behaviour to the wrongdoer after the decision, while praying, to give it. The fulfilment of this second condition thus constitutes our small contribution to reparation for our sins.

As far as I can see, the only discussion in Stump's book of these Gospel passages implying that Christ taught that God's forgiveness of us is not unconditional is contained in a short note. ${ }^{14}$ Stump begs the question in favour of her interpretation in the very first sentence of that note, by describing these passages as "passages that seem to imply that God's love and forgiveness are conditional," and so assuming what she needs to demonstrate-that forgiveness (in the sense in which the Gospel writers are interpreting Christ) is simply an inevitable expression of love. She rejects the natural interpretation of Matthew 6:15, on the grounds that on

${ }^{14}$ Stump, Atonement, 440n61. 
that interpretation "the saying would be at least in serious tension with other texts, such as God telling people to love their enemies so that they will be like God, who sends his good gifts on both the just and the unjust." (Matthew 5:45). But in my sense of "forgive" which is what I am claiming to be Christ's sense, there is no tension at all. We can still love someone whom we do not forgive (in my sense), because we respect their wish to be taken seriously as a person who wants to deprive us of what we think they owe us, while hoping for and working towards a situation where they will seek our forgiveness - if necessary, by keeping our distance from them. And we can also forgive those whom we do not love; people often report forgiving others for self-centred reasons merely in order to stop feeling bitter and to "move on" in life. Stump comments on the parable of the two debtors that "the King (who represents God in the parable) is portrayed as forgiving his servant first, before the episode in which the serpent failed to forgive his fellow servant," and interprets that as showing that God forgives without conditions. But the king does not forgive the first servant until the latter asks for some relief of his obligation (in the form of a longer time in which to repay his debt), and - we may reasonably assume-in so doing made a repentant apology. And the parable only makes sense if the King has the right to withdraw his forgiveness of the debt; and that could only be the case if the King's forgiveness was given on the assumption that the debtor intended to show similar forgiveness to those indebted to him. That assumption proved mistaken, since immediately after his interview with the king the servant demanded repayment from his fellow servant, and so the king had the right to withdraw his forgiveness.

The passages in the Gospels which Stump finds as the most illuminating for our understanding of forgiveness are the parable of the Prodigal Son and Christ's words from the Cross, "Father, forgive them; for they do not know what they are doing" (Luke 23:34). In the parable of the Prodigal son (Luke 15:11-31) the father gives his younger son his share of his expected inheritance and the son goes away to a far country and spends it all. Then the son comes to his senses, wants to go home, prepares words of apology, and makes the long journey home. His father sees his son returning, "runs out to meet him ... , falls on his son's neck and kisses him" before the son could make his apology, "I have sinned against heaven and before you." I think that Christ (as reported by Luke) means us to understand that the son is genuinely repentant, and for her purposes in analysing different theories of forgiveness, Stump also makes that assumption. ${ }^{15}$ I suspect that Christ also means us to understand that the father knows that the son is repentant simply because he sees him coming home, and for her purposes Stump is willing to make that assumption also. It certainly also looks as if Christ means us to understand that the father is showing his forgiveness by putting his arms around the son and kissing him before the son utters his words of repentance; and, like Stump, I am happy to make

\footnotetext{
${ }^{15}$ Stump, Atonement, 63-65.
} 
that assumption also. But Stump claims that if we adopt the Anselmian approach to satisfaction, we cannot interpret the parable in that way; "On the Anselmian approach, ... satisfaction is and ought to be a requisite for forgiveness and reconciliation"; ${ }^{\prime 6}$ the father cannot properly forgive his son until the son has made satisfaction. But on my version of Anselm's theory I denied that that holds universally; everything depends on the particular case. So we need to be clear about what wrong the son has done. The father has already given him his share of the inheritance, and is not proposing to give him any more-as, after the younger son's return, he said to the elder son "all that is mine is yours." The wrong done is to deprive his father of his company and affection for a significant time and to lead the father to suppose that he will never see his son again. This is a serious wrong, and it is plausible to suppose that it would be bad for the father to forgive the son unless the son had taken some small steps to make reparation for that wrong. But the son has already made some steps of a kind appropriate to that wrong-literal steps in making the long journey home, and asking to stay there permanently; he is now doing his best to repair the damage, and so the father's forgiveness is a response to that attempt. On my version of the Anselmian theory that it is up to the wronged person to determine how much reparation is enough of a response sufficient to justify full forgiveness, the father is entitled to regard that response as sufficient to make it good for him to forgive the son.

Stump takes Christ's words from the Cross as showing that Christ considers that it is good to forgive even when there is no "repentance on the part of the wrongdoers." ${ }^{17}$ But in expounding my Anselmian account I wrote that my

account of repentance and apology applies in so far as there is an element of subjectivity in the guilt, in so far as deliberately or through negligence the wrongdoer has some moral responsibility for doing the harm. If the guilt is purely objective, arising from the performance of an unintentional act in performing which there was not even the slightest negligence involved ... an apology (but one which brings out the unintentional character of the action) is needed; but it needs behind it no repentance in the form of change of mind. ${ }^{18}$

We are not blameworthy for doing actions whose wrong nature we do not in any way realize; and we can only be blameworthy for not apologising for an unintentional wrong action after we realise that it was a wrong action. So it is plausible to suppose that God would be right to forgive those "who do not know not what they are doing," without that affecting the main point that God would not be right to forgive those who do know what they are doing without them repenting and apologising.

\footnotetext{
${ }^{16}$ Stump, Atonement, 64.

${ }^{17}$ Stump, Atonement, 111.

${ }^{18}$ Swinburne, Responsibility and Atonement, 83.
} 
In her subsequent paper, ${ }^{19}$ Stump has given an example of a case where, she claims, we cannot interpret Matthew 6:15 as claiming that forgiveness should not be given without repentance on the part of the wrongdoer. The example concerns the goodness of forgiving someone who is now dead and so not capable of apologising. But whatever one thinks that God expects a living human to do in response to the wrongdoing of someone now dead (which is a special case which I explicitly discuss in Responsibility and Atonement ${ }^{20}$ ) it does not affect the basic point of Christ's teaching that God is only going to forgive us if we forgive those whom we are in a position to forgive when they ask for our forgiveness. I conclude that Stump's preferred account of the sense of the Gospel word normally translated as "forgive" is not Christ's sense, and so will badly mislead those who take it as a guide to Christ's teaching on when we should forgive others and God will forgive us.

Further, I argue on independent moral grounds, those who are wronged and love the wrongdoer should both take the wrongdoer seriously as a person who wishes to hurt them by depriving them of what is owed to them, and also show them that it matters very much that they should repair the wrong done. Those who wrong us are free agents whose attitude towards us ought to be respected and not ignored; and it is good to help them to see the error of their attitude and the need to repair the wrong done. Hence those who are wronged should take a different stance towards the wrongdoer who is unwilling to repent from the stance taken towards a repentant wrongdoer; and the obvious way to express this point is to say that it is good not to "forgive" a serious wrong without some sign of atonement, at least by some sort of repentant apology; but of course it is good to "forgive" after a degree of atonement, the degree required being a function of the harm done. To some extent Stump recognises this point but puts it in different words, when she claims that even though it is obligatory to "forgive" immediately and without conditions, "grave moral evil can leave a wrongdoer in such a condition that without some remedy for a stain on his soul and some way of making sufficient amendments, reconciliation with him is ruled out on moral grounds," and so it would still be in place to "require punishment" of someone penitent and forgiven. ${ }^{21}$ Now certainly on my Anselmian account, just as one can remit a monetary debt subject to the fulfilment of some condition by the debtor, so too (as I acknowledged above) one can make one's forgiveness subject to some assumption about the wrongdoer's current intentions. But one can only "punish" someone if one treats them as someone who has done wrong; and on my Anselmian account, to forgive someone is to put them in the same

\footnotetext{
${ }^{19}$ Stump, "The Doctrine of the Atonement."

${ }^{20}$ Swinburne, Responsibility and Atonement, 88-89.

${ }^{21}$ Stump, Atonement, 100.
} 
position as someone who has not done wrong. The kind of "reconciliation" which Stump acknowledges is good should happen, is, as she pictures it, a gradual process. So her account seems to leave the great concept of the wronged person totally and completely "wiping the slate clean," so that she deems the wrongdoer not to have wronged her, without a separate word to describe it when there is already a very suitable word available to describe it. It is more than "forgiveness plus reconciliation" 22 which Stump analyses as an alternative sense of "forgiveness," since for her "reconciliation" is "the union in love of whatever kind of uniting is suitable for persons being united after being apart." ${ }^{23}$ Or rather it is reconciliation of a particular kind. It is not merely the end of "alienation, and desiring something bad for the wrongdoer" which Stump associates with reconciliation, ${ }^{24}$ but consists in treating the wrongdoer as someone who has not wronged you. Yet so valuable is it in human interaction that this should happen as often as possible, whenever wrong is done, that Stump's account just fails to give it the value which deserves. That is why forgiveness (in what I have argued is Christ's sense) of other humans is sometimes so difficult. If I could forgive someone simply by having the kind of friendly intercourse with them that I had had previously and wishing them no harm while still bearing in mind the wrong they had done to me, it wouldn't be so difficult to forgive them. According to St Paul's teaching in the Letter to the Romans, we (that is, presumably those who have repented and been baptised) have been "justified" by the blood of Christ; in the sight of God we are now "just." God gives us this status on the assumption that we intend to behave justly in future. Given that we do so intend (and God, unlike the King in the parable of the debtors, will know whether or not we do so intend), this status is not a provisional one. God has wiped the slate clean. If God sends some penitent sinners to Purgatory, it cannot be as a "punishment" for their sins, but only as a means of making their intentions more steadfast, so that they acquire a character which fits them for heaven.

\section{III}

In presenting her own account of the purpose of the Passion of Christ, Stump has a further criticism of my account of the Atonement. She seems to reject the view of the Letter to the Hebrews and subsequent Christian tradition that Christ's death on the cross constituted a "sacrifice" by Christ to God. "In the most primitive way of thinking about sacrifice lying behind Old Testament thought, a sacrifice is the giving of something valuable to God who consumes it whole (by inhaling the smoke) and often gives back some of it to be consumed by the worshippers (who eat the roasted flesh)." ${ }^{25}$ Stump is right to emphasise that, in Old Testament thought,

\footnotetext{
${ }^{22}$ Stump, "The Doctrine of the Atonement," 177.

${ }^{23}$ Stump, Atonement, 433 n.1.

${ }^{24}$ Stump, "The Doctrine of the Atonement," 178.

${ }^{25}$ Swinburne, Responsibility and Atonement, 152.
} 
worshippers offer sacrifice for many different reasons apart from seeking at-onement with God. But it remains the case that offering sacrifice is a normal way of "making amends to the deity," 26 and the Letter to the Hebrews makes it very clear that by his death Christ "offered for all time a single sacrifice for sins ( $\alpha \mu \alpha \varrho \tau i ́ \alpha \varsigma^{\prime \prime}$ (Hebrews 10:12) - not a verse cited by Stump). Stump writes: "The sacrifices that are mandated for offences in the Hebrew Bible are often animal sacrifices. On the idea represented by Swinburne's interpretation of sacrifice, something about killing an animal makes an offended God more likely to pardon the offending human being, or more likely to forgo imposing punishment on the human being who deserves it." ${ }^{27}$ Of course the ancient Hebrews thought that sacrificing dead animals would be giving to God something valuable. But, as the Letter to the Hebrews asserted, "it is impossible for the blood of bulls and goats to take away sins" (Hebrews 10:4). God wants an offering of something really valuable, and that must be something that he does not already have. As Stump goes on to acknowledge, ${ }^{28}$ I claimed that what Christ offered was just that - a human life lived perfectly. ${ }^{29}$ Stump criticises this account of what Christ offered to God on the ground that in claiming that Christ's whole life was a sacrifice, I have made "Christ's passion and death seem marginalized or incidental and not central to the present offered to God, as they need to be on traditional Christian views about Christ as sacrifice." ${ }^{30}$ I don't think so. Christ was crucified because he lived a perfect human life by living the life of a wandering rabbi, befriending prostitutes, tax collectors, and lepers; and telling the rulers and influential people of his society how they ought to live (including not to respond to force with force), how sinful they were, and that he was the Messiah sent to tell them this. The Jewish leaders got him crucified because they resented his words and actions and feared their effects; and he ended his life living up to his own teaching by voluntarily not using force to resist force. Being prepared to die for living a certain kind of life exhibits the maximum degree of living that kind of life; Christ said "no one has greater love than this, to lay down one's life for one's friends" (John 15:13). Stump finds it "very hard to understand why the present [of Christ to God] "includes centrally the suffering and death of an innocent human being." But if that is a problem, it is a problem for any account of the Atonement. And Christian tradition has not regarded it as a problem, because it has seen that that innocent human being suffering on the cross being God himself, is God's glory and triumph, not a disaster. In the words of the Passiontide hymn, "He reigns from the tree."

\footnotetext{
${ }^{26}$ Stump, Atonement, 382.

${ }^{27}$ Stump, Atonement, 382.

${ }^{28}$ Stump, Atonement, 395.

${ }^{29}$ Swinburne, Responsibility and Atonement,152-155.

${ }^{30}$ Stump, Atonement, 395.
} 
So I reject all Stump's criticisms of my version of an Anselmian account of the Atonement. Her account of forgiveness is not that of the Christ of the Gospels, and in consequence it does not bring out the importance of a kind of human interaction vital for human well-being. And it fails to understand the enormous value of the Passion and death of Christ, constituted by a "sacrifice" in the sense understood in the Letter to the Hebrews. But my Anselmian account of the Atonement is totally compatible with Stump's own account (which I have not discussed), of how Christ acted to make humans at-one with God, so long as the latter is regarded only as a way in which God acted, additional to Christ making available his life and death as a reparation for our sins which we can offer to God, in consequence of which God treats those who offer it as not having sinned.

Oriel College, Oxford

\section{References}

Anselm, Cur Deus Homo.

Aquinas, Thomas. 1964. Summa Theologiae (Blackfriars).

Stump, Eleonore. 2018. Atonement (Oxford University Press). https://doi.org/10.1093/oso/9780198813866.001.0001

Stump, Eleonore. 2019. "The Doctrine of the Atonement: Responses to Michael Rea, Trent Dougherty, and Brandon Warmke." European Journal for Philosophy of Religion 11: 165-186. https://doi.org/10.24204/ejpr.v11i1.2710

Swinburne, Richard. 1989. Responsibility and Atonement (Oxford University Press). https://doi.org/10.1093/0198248490.001.0001 